\title{
EFFECT OF REAGENT TYPE ON THE FROTH FLOATATION OF SOKOTO PHOSPHATE ORE
}

\author{
U.A. Hassan ${ }^{1}$, S.A. Yaro ${ }^{2}$, M. Abdulwahab ${ }^{3}$, M.R. Dodo ${ }^{3 *}$ \\ ${ }^{1}$ Federal ministry of solid minerals, Nigeria \\ ${ }^{2}$ Shell Professor, Department of Mechanical Engineering, Ahmadu Bello \\ University, Nigeria \\ ${ }^{3}$ Department of Metallurgical and Materials Engineering, Ahmadu Bello \\ University Zaria, Nigeria
}

Received 12.04.2016

Accepted 16.05.2016

\begin{abstract}
Effect of reagent type on the froth floatation of Sokoto phosphate ore for its beneficiation has been established. The samples of the Sokoto phosphate mineral ore used for the research work were sourced from mining locations in Dange-Shuni, Bodinga, Yabo, Wurno, and Rabbah Local Government Areas of Sokoto State. SizeAssay analysis conducted on scrubbed Sokoto Phosphates nodules revealed that nodules had a size distribution with $80 \%$ passing $29.3 \mathrm{~mm}$. Flotation Tests using AERO704 (fatty Acid), Alkyl Hydroxamates, Melamine as collectors (alone or mixed with diesel), $\mathrm{MIBC}$ as frother, Calcium Hydroxide and Sulphuric Acid as $\mathrm{pH}$ regulators and Dextrin, Sodium Silicate and Aluminium Chloride as depressants produced poor $\mathrm{P}_{2} \mathrm{O}_{5}$ separation in the flotation products due to very poor liberation associated with very fine mineral grains. Based on the results obtained, AERO704 Collector gave the best result with a $\mathrm{P}_{2} \mathrm{O}_{5}$ recovery of $87.3 \%$ at $950 \mathrm{~g} / \mathrm{t}$ of reagent, $65 \%$ solid conditioning pulp density and $\mathrm{pH}$ of 10 .

Keywords: Sokoto phosphate rock, beneficiation, deposit, metallurgical grade, AERO 704 (fatty Acid), Flotation, Alkyl Hydroxamates, Melamine.
\end{abstract}

\section{Introduction}

Phosphate mineral is used as a main component in the manufacture of fertilizer that provides phosphorus nutrients required by plants. Phosphorus replenishment of soil is currently efficiently achieved by direct application of phosphorus fertilizer to the soil. Phosphate products are also utilized in manufacture of animal feeds, detergent, and in various industrial processes such as in the control of rust and prevention of corrosion of

\footnotetext{
*Corresponding author: Mamuda Rayyan Dodo, rdmamuda@abu.edu.ng
} 
ferrous materials applied with electrochemical conversion coatings. Phosphate mineral is also one of the basic raw materials in the manufacture of phosphoric acid and phosphorus based detergents [1].

The Nigerian demand for phosphate rock is estimated to be about 200,000 tonnes per annum with local production put at 20,000 tonnes per annum [2]. The increasing local demand for phosphate by the user industry especially for fertilizer production due to increased need to boost farm produce coupled with the global economic instability has made it mandatory for Nigeria to strive to develop her phosphate resources.

It is worthy to note that phosphate minerals are not found everywhere in the right concentration needed for optimum plant growth; thus the need to artificially add this mineral to the soil in the form of fertilizer. In view of the strategic importance of fertilizer to food security since no tangible farm produce can be produced without fertilizer and the fact that no known fertilizer grade is currently produced in the country, this makes the research apt. Hence, there is need to beneficiate the Sokoto phosphate rock deposit to a metallurgical grade, so that it can be used as feed for the production of fertilizer and other phosphorus based products.

\section{Materials and methods}

\section{Samples}

$50 \mathrm{~kg}$ of blended Sokoto Phosphate nodules obtained from Fifty (50) Sokoto Phosphate ore samples randomly collected (ten each) from artisanal miners in DangeShuni, Bodinga, Yabo, Wurno, and Rabbah Local Government Areas of Sokoto State were used for the research work.

\section{Equipment/Apparatus}

Denver flotation cell, XRF, small size laboratory jaw crusher, cone crusher, pulverizing machine, standard sieve shakers (sieve size fractions: $-250+180 \mu \mathrm{m}$, $-180+106 \mu \mathrm{m},-106+75 \mu \mathrm{m},-75+38 \mu \mathrm{m})$, Wifley shaking table.

\section{Reagents}

Reagents used during the research work comprised AERO704 (Fatty Acid), sodium carbonate, Reagent S-9849, (an alcoholic solution of alkyl hydroxamic acid from Cytec), Aerofroth 70 (methylisobutylcarbinol - MIBC), Dextrin, Phosphoric Acid and Melamine.

\section{Methodology}

Composite sample of Sokoto phosphate rock was subjected to the laboratory separation tests.

\section{Laboratory Separation test}

Bench Scale Flotation Tests

Bench Scale flotation tests were carried out on $-250+180 \mu \mathrm{m},-180+106 \mu \mathrm{m}$, $-106+75 \mu \mathrm{m},-75+45 \mu \mathrm{m}$ and $-45+38 \mu \mathrm{m}$ particle size fractions after screening in order to determine the optimum flotation feed size distribution using 1 liter Denver flotation cell.

The procedures for carrying out the test are as follows:

Predetermined volume of water was added into the one Liter flotation cell, depending on the conditioning pulp density $(55 \%, 60 \%$ and $65 \%$ adopted based on findings by Zhang [3]) to be used. 350g of ground phosphate rock was then added and 
conditioned for two minutes at desired percent solids (55\%, 60\% and 65\%). Make up water was added and mixed for thirty seconds. Air was then introduced with floated material collected until froth contains clean air bubbles. Collected float materials were dried in an oven and analyzed for $\mathrm{P}_{2} \mathrm{O}_{5}$ using XRF Pan Analytical Mini PAL4 analyzer.

\section{Results and discussion}

Table I gives the percentage of chemical compounds present in the float (concentrate) and tailings products floated using various reagents, $\mathrm{pH}(\mathrm{s})$ at different sieve size fractions and flotation conditions. Figures 1 and 2 show $\%$ assay of the chemical compounds in the products recovered from the froth flotation processes using Reagent S-9849 Promoter (Alkyl Hydroxamates) and melamine reagents respectively.

From the result, an average of $50 \% \mathrm{CaO}$ and $20 \% \mathrm{P}_{2} \mathrm{O}_{5}$, are floated into the float (concentrate), while $10 \% \mathrm{Fe}_{2} \mathrm{O}_{3}$ and less than $10 \% \mathrm{SiO}_{2}$ are floated alongside with the $\mathrm{CaO}$ and $\mathrm{P}_{2} \mathrm{O}_{5}$ into the float. The separation of the chemical compound of the Sokoto phosphate mineral ore into float and tailings given in Table I show that the Sokoto phosphate ore could respond to froth flotation condition processes and hence could be beneficiated using froth flotation mineral processing technique as stated by Weiss [4]. Weiss [4] explained that froth flotation process is the widely adoptable method in the beneficiating of phosphate mineral ores in US.

The average value of $22.6 \% \mathrm{P}_{2} \mathrm{O}_{5}$ content obtained in the flotation of the Sokoto phosphate rock using a blended sample of scrubbed material is less than the 28.50 to $33.10 \% \mathrm{P}_{2} \mathrm{O}_{5}$ contents of that obtained in the flotation processes of the US phosphate mineral ores due to non-liberation of the various mineral components arising from its collophane nature. The iron contents obtained were also higher than that of the US. The $\% \mathrm{CaO}$ contents obtained for the flotation of the Sokoto phosphate is higher when compared to the values obtained for the beneficiation of US phosphate mineral ores using the Crago methods of flotation processes. This could be attributed to the intimate association between the phosphate bearing minerals and the fact that iron and silica have been found to interfere with the chemistry of flotation process of apatite (phosphate) mineral ores [4]. 


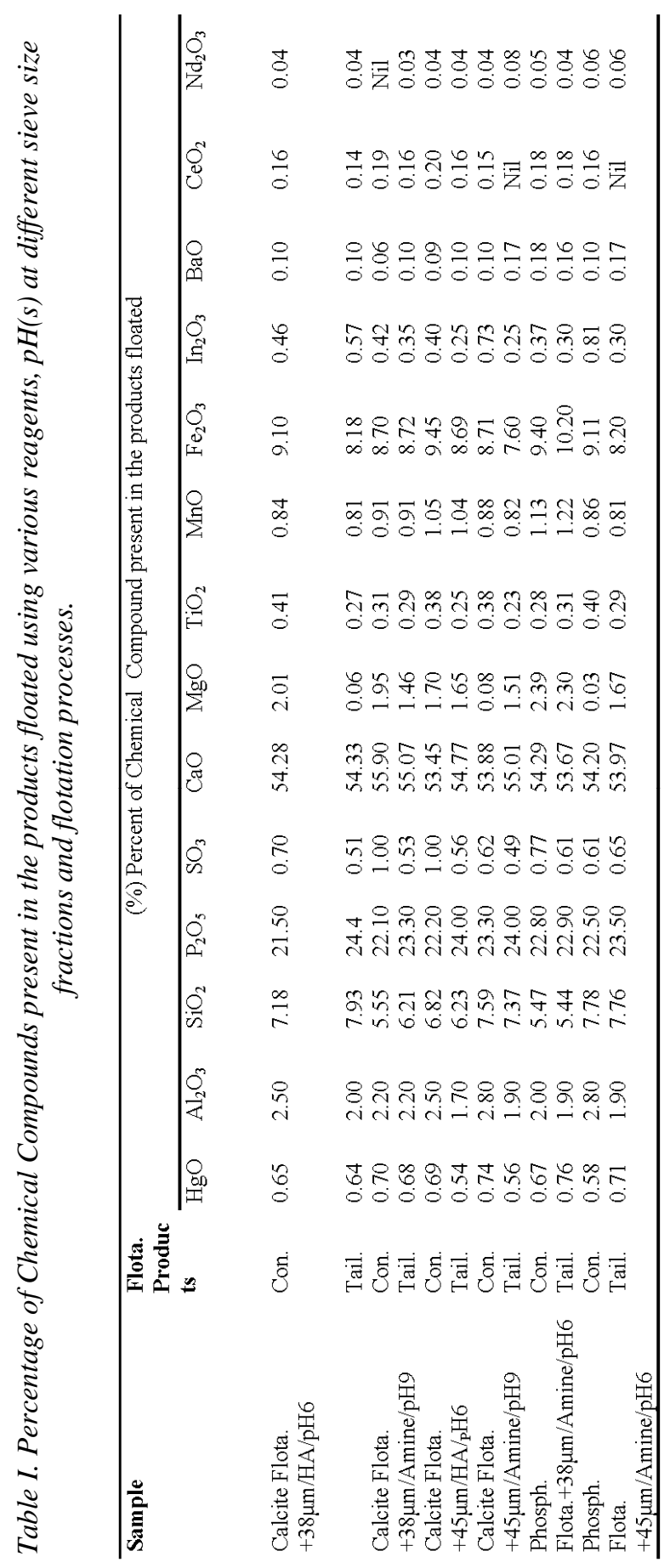


Table II and Figures 3 and 4 respectively represent the assays of $\% \mathrm{P}_{2} \mathrm{O}_{5}$ and $\%$ recoveries of $\mathrm{P}_{2} \mathrm{O}_{5}$ into the floats and tailings for the scoping studies on $-106+38 \mu \mathrm{m}$ size fraction using $800 \mathrm{~g} / \mathrm{t}$ of various reagent types with sodium silicate and aluminu chloride as depressants for calcite at $25 \%$ solids and conditioning pulp density of $60 \%$ solids and pH9. The results depict that diesel/AERO704 had a better recovery of $60.4 \%$ when compared with the recoveries of 55.4\% and $48.8 \%$ respectively recorded for AERO704 alone and Alkyl Hydroxamates. These values are however lower than the recovery figures recorded when AERO704 (76.2\%) and Alkyl Hydroxamates (61.5\%) were used without any depressants. The grades of the various fractions collected showed mild differences as they all fell within the less than $25 \% \mathrm{P}_{2} \mathrm{O}_{5}$ category indicating poor separation arising from non-liberation of mineral components due to the very fine grain sizes of the associating mineral assemblage coupled with the high content of iron and calcite which significantly affect phosphate flotation [4].

These results show that using AERO704 collector alone and without any depressant in floating Sokoto phosphate rock will give better recovery results than either Alkyl Hydroxamates or AERO704 combined with Diesel.

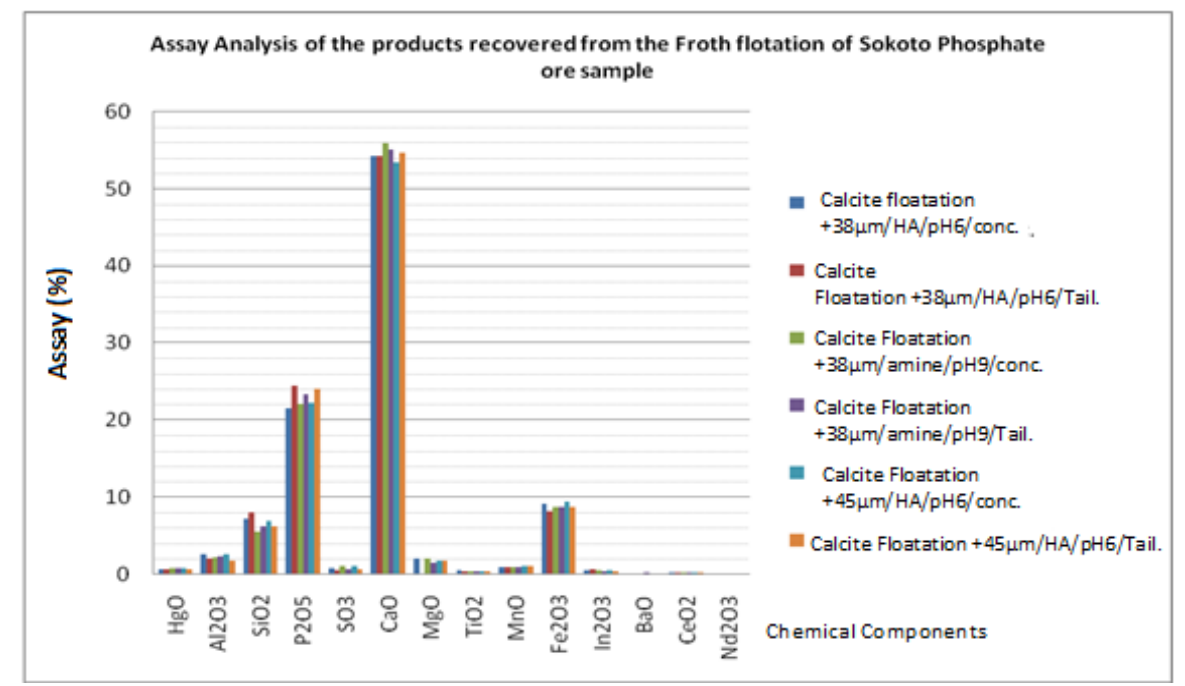

Fig. 1. Assay of the chemical compound in the products recovered from the froth flotation of Sokoto phosphate Rock sample using Alkyl Hydroxamates (HA) and Melamine reagents. 
Table II: Results of Scoping Studies on $-106+38 \mu \mathrm{m}$ size fraction using $800 \mathrm{~g} / \mathrm{t}$ of various Reagent Types with Sodium Silicate and Aluminum Chloride as depressants for calcite at 25\% solids and conditioning pulp density of $60 \%$ solids and $\mathrm{pH} 9$.

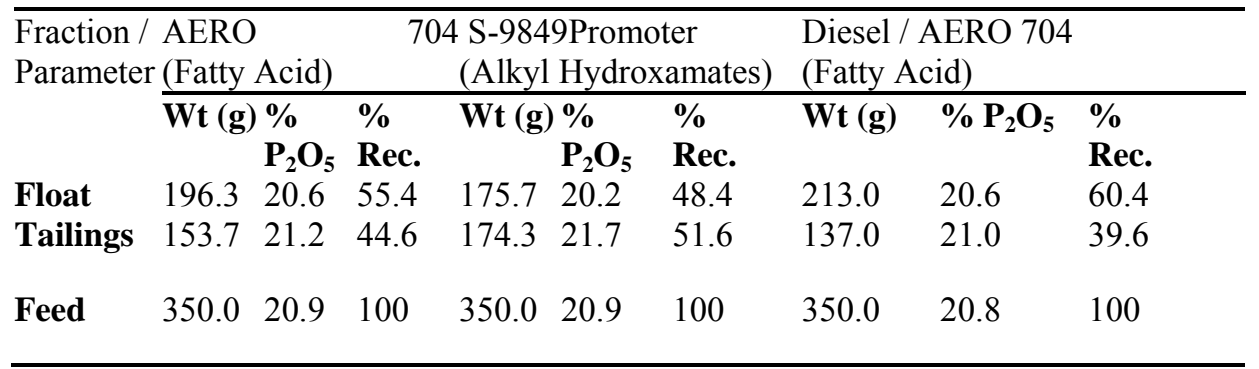

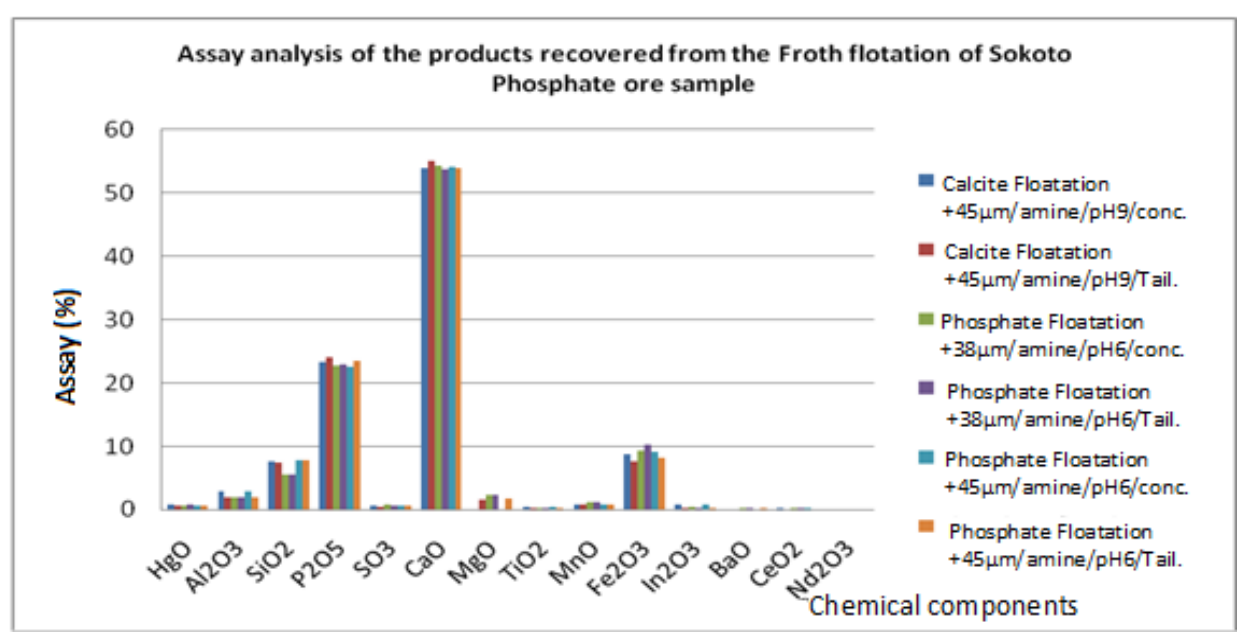

Fig. 2. \% assay of the chemical compound in the products recovered from the froth flotation of Sokoto phosphate ore sample using Melamine reagent only.

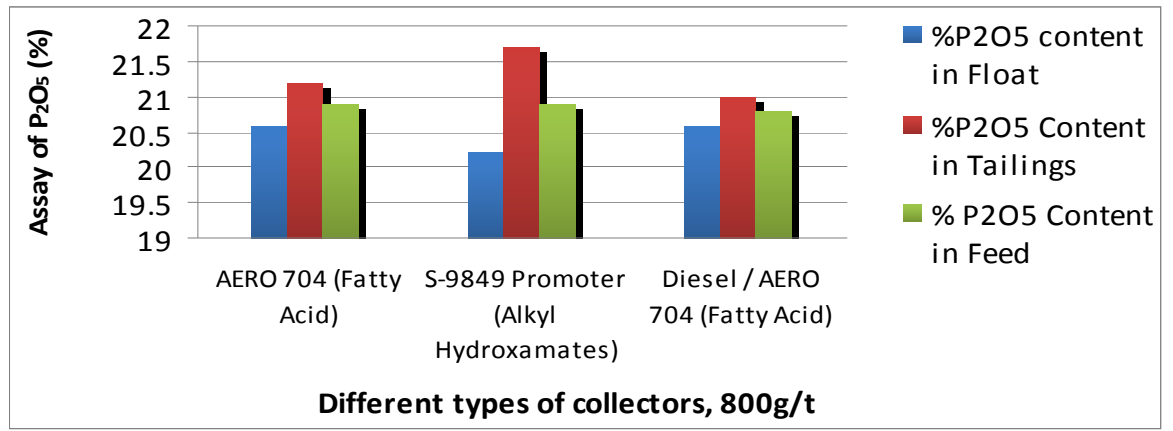

Fig. 3. Assays of $\% \mathrm{P}_{2} \mathrm{O}_{5}$ infloats and tailings for Scoping Studies on $-106+38 \mu \mathrm{m}$ size fraction using $800 \mathrm{~g} / \mathrm{t}$ of various reagent types with Sodium Silicate and Aluminum Chloride as depressants for calcite at $25 \%$ solids and conditioning pulp density of $60 \%$ solids and $\mathrm{pH} 9$. 


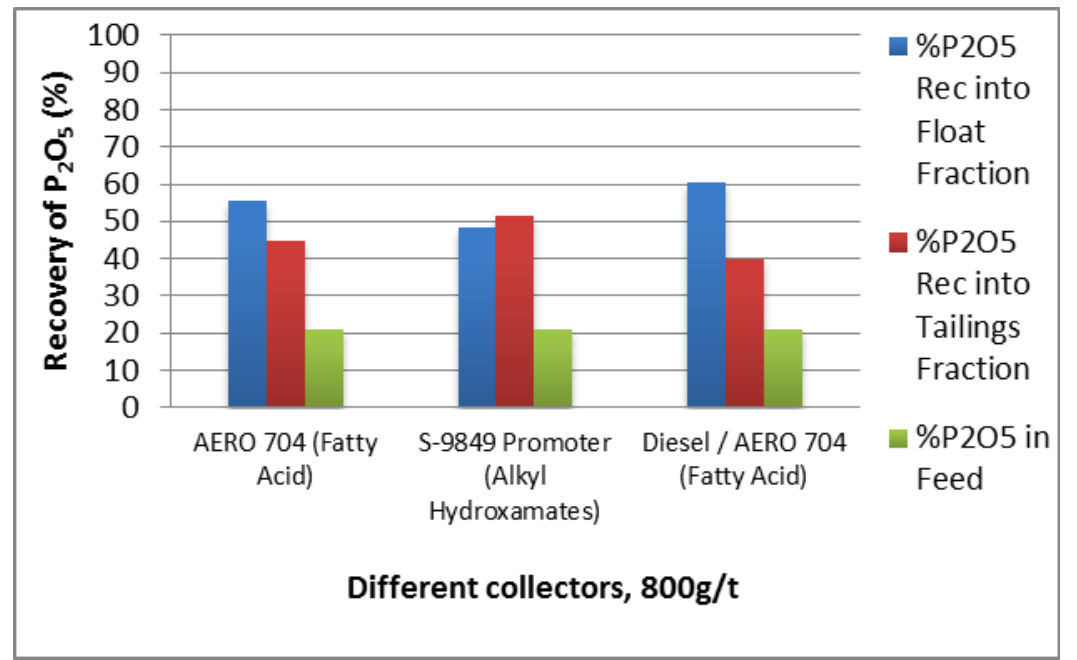

Fig. 4. \% Recovery of $\mathrm{P}_{2} \mathrm{O}_{5}$ into flotation fractions of Scoping Studies on $-106+38 \mu \mathrm{m}$ size fraction using $800 \mathrm{~g} / \mathrm{t}$ of various reagent types with sodium silicate and aluminum chloride as depressants for calcite at $25 \%$ solids and conditioning pulp density of $60 \%$ solids and $\mathrm{pH} 9$.

Table III and Figures 5 and 6 show \% assay of $\mathrm{P}_{2} \mathrm{O}_{5}$ and recovery in the flotation products of $-106+38 \mu \mathrm{m}$ at $28.5 \%$ solids with AERO704 Promoter (Distilled Tall-oil Fatty Acids) and Methyl isobutyl carbinol (MBIC) frother reagents at $\mathrm{pH} 8$ and conditioning pulp densities of $55 \%$ solids and $65 \%$ solids and reagent dosages of $500 \mathrm{~g} / \mathrm{t}$ and $950 \mathrm{~g} / \mathrm{t}$. From the results, the floats obtained by conditioning at $55 \%$ solids with a reagent dosage of $500 \mathrm{~g} / \mathrm{t}$ had an assay of $19.0 \% \mathrm{P}_{2} \mathrm{O}_{5}$ and a recovery of $70.5 \%$ which is less than the assay values obtained by conditioning at $65 \%$ solids with $500 \mathrm{~g} / \mathrm{t}$ reagent dosage $\left(20.3 \% \mathrm{P}_{2} \mathrm{O}_{5}\right.$ and a recovery of $\left.72.5 \%\right)$. The differences in the values of the $\%$ assays of $\mathrm{P}_{2} \mathrm{O}_{5}$ contents and \% recoveries of the floats are significantly very small and this could be attributed to the differences in the percent of solids floated. Where the higher the $\%$ of solids floated the higher the tendency for more $\%$ of the phosphate bearing minerals to report in the float. Similar reasoning could be advanced for the $55 \%$ and $65 \%$ solids of the $950 \mathrm{~g} / \mathrm{t}$. The tailings of the $55 \%$ and $65 \%$ of the $500 \mathrm{~g} / \mathrm{t}$ and $950 \mathrm{~g} / \mathrm{t}$ have higher contents of $\%$ assays of the $\mathrm{P}_{2} \mathrm{O}_{5}$ and low $\%$ recoveries values of the phosphate bearing minerals. This could be attributed to the combined efficiency of the two promoters' reagent that enhances the transferred of much volume of the phosphate bearing minerals to the froth phase as floats (concentrates). 
Table III: Floatation Test using - 106+38 $\mu \mathrm{m}$ size fraction at $28.5 \%$ solids with AERO 704 Promoter (Distilled Tall-oil Fatty Acids) and Methyl isobutyl carbinol (MBIC) frother at $\mathrm{pH} 8$

\begin{tabular}{|c|c|c|c|c|c|c|c|c|}
\hline \multirow{4}{*}{$\begin{array}{l}\text { Fractions/ } \\
\text { Parameter }\end{array}$} & \multicolumn{8}{|c|}{$\mathrm{pH} 8$} \\
\hline & \multicolumn{4}{|c|}{$500 \mathrm{~g} / \mathrm{t}$} & \multicolumn{4}{|c|}{$950 \mathrm{~g} / \mathrm{t}$} \\
\hline & $55 \%$ solids & & $65 \%$ solids & & $55 \%$ solids & & $65 \%$ solids & \\
\hline & $\mathrm{Wt}(\mathrm{g}) \%$ & $\%$ & $\mathrm{Wt} \quad \%$ & $\%$ & $\mathrm{Wt} \quad \%$ & $\%$ & $\mathrm{Wt} \quad \%$ & $\%$ \\
\hline & $\mathrm{P}_{2} \mathrm{O}_{5}$ & Rec. & (g) $\quad \mathrm{P}_{2} \mathrm{O}_{5}$ & Rec. & (g) $\quad \mathrm{P}_{2} \mathrm{O}_{5}$ & Rec. & (g) $\quad \mathrm{P}_{2} \mathrm{O}_{5}$ & Rec. \\
\hline Floats & 250.219 .0 & 70.5 & 256.320 .3 & 72.5 & 234.220 .0 & 66.0 & 257.720 .4 & 72.7 \\
\hline Tailings & $99.8 \quad 20.9$ & 29.5 & $93.7 \quad 21.1$ & 27.5 & 115.820 .8 & 34.0 & $92.3 \quad 21.6$ & 28.3 \\
\hline Feed & 350.0 & 100 & 350.020 .5 & 100 & 350.020 .3 & 100 & 350.020 .7 & 100 \\
\hline
\end{tabular}

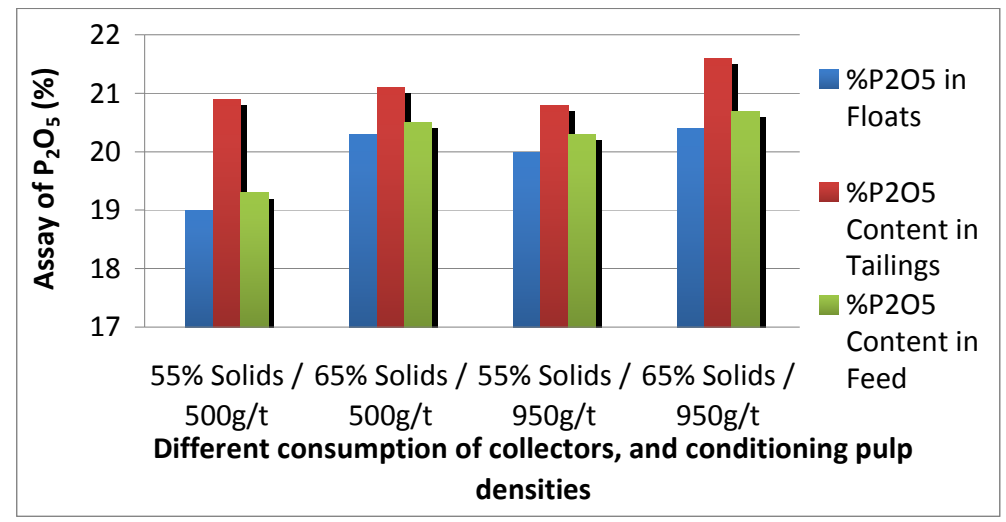

Fig. 5. \% Assay of $\mathrm{P}_{2} \mathrm{O}_{5}$ of the flotation fractions of $-106+38 \mu \mathrm{m}$ at $\mathrm{pH} / \mathrm{AERO}$ - 04 Promoter/MBIC (frother).

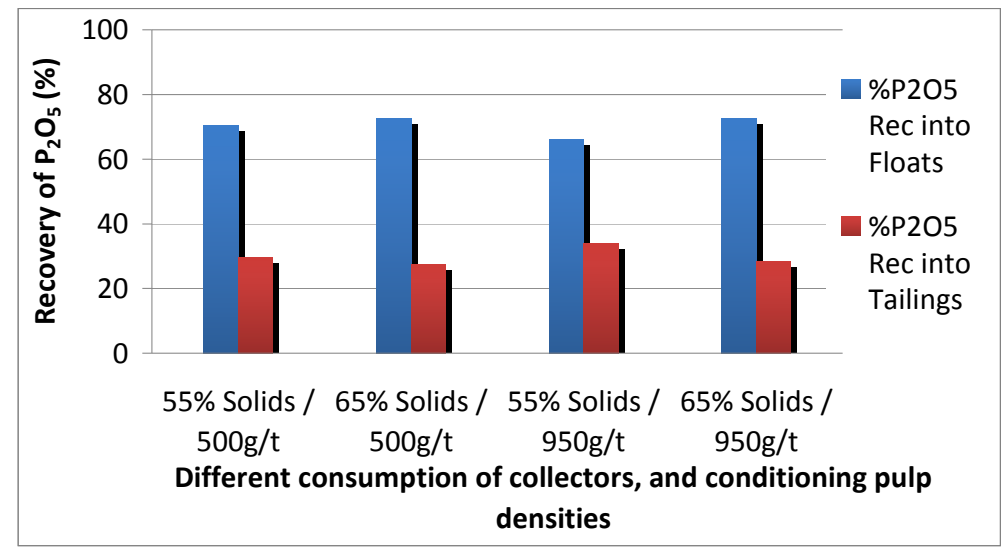

Fig. 6. \% Recovery of $\mathrm{P}_{2} \mathrm{O}_{5}$ of the flotation fractions of $-106+38 \mu \mathrm{m}$ at $\mathrm{pH} 8 / \mathrm{AERO} 04$ Promoter/MBIC (frother). 
Table IV and Figures 7 and 8 depict \% assay of $\mathrm{P}_{2} \mathrm{O}_{5}$ contents and recovery of the flotation products of $-106+38 \mu \mathrm{m}$ at $\mathrm{pH} 10 / \mathrm{AERO} 704$ Promoter (Distilled Tall-oil Fatty Acids) and Methyl isobutyl carbinol (MBIC) frother reagents. From the results, the floats of $55 \%$ solids have an assay of $20.4 \% \mathrm{P}_{2} \mathrm{O}_{5}$ and a recovery of $75.2 \%$ more than the values obtained for the floats of $65 \%$ solids assaying $18.5 \% \mathrm{P}_{2} \mathrm{O}_{5}$ but with a higher recovery of $78.9 \%$ for $500 \mathrm{~g} / \mathrm{t}$. The differences in the values of the $\%$ assays of $\mathrm{P}_{2} \mathrm{O}_{5}$ contents and \% recoveries of the floats are significantly small and this could be attributed to the differences in the percent of solids floated. The higher the \% of solids floated the higher the tendency for more $\%$ of the phosphate bearing minerals to report in the float. Similar reasoning could be advanced for the $55 \%$ and $65 \%$ solids of the $950 \mathrm{~g} / \mathrm{t}$. The tailings of the $55 \%$ and $65 \%$ of the $500 \mathrm{~g} / \mathrm{t}$ and $950 \mathrm{~g} / \mathrm{t}$ have higher contents of $\%$ assays of the $\mathrm{P}_{2} \mathrm{O}_{5}$ and low $\%$ recoveries values of the phosphate bearing minerals. This might be due to the combined efficiency of the two promoters' reagent that enhances the transfer of much volume of the phosphate bearing minerals to the froth phase as floats (concentrates).

Table IV: Floatation Test using $350 \mathrm{~g}$ of - $106+38 \mu \mathrm{m}$ size fraction at $28.5 \%$ solids with AERO ${ }^{\circledR 704}$ Promoter (Distilled Tall-oil Fatty Acids) and Methyl isobutyl carbinol (MBIC) frother at $\mathrm{pH} 10$

\begin{tabular}{|c|c|c|c|c|c|c|c|c|}
\hline \multirow{5}{*}{$\begin{array}{l}\text { Fractions/ } \\
\text { Parameter }\end{array}$} & \multicolumn{8}{|c|}{$\mathrm{pH} 10$} \\
\hline & \multicolumn{4}{|c|}{$500 \mathrm{~g} / \mathrm{t}$} & \multicolumn{4}{|c|}{$950 \mathrm{~g} / \mathrm{t}$} \\
\hline & \multicolumn{3}{|c|}{$55 \%$ solids } & $65 \%$ solids & \multicolumn{2}{|c|}{$55 \%$ solids } & \multicolumn{2}{|c|}{$65 \%$ solids } \\
\hline & $\mathrm{Wt}(\mathrm{g})$ & $\% \mathrm{P}_{2}$ & $5 \%$ & $\mathrm{Wt} \quad \% \quad \%$ & $\mathrm{Wt} \%$ & $\%$ & $\mathrm{Wt} \quad \%$ & $\%$ \\
\hline & & & Rec. & (g) $\quad \mathrm{P}_{2} \mathrm{O}_{5}$ Rec. & (g) $\mathrm{P}_{2} \mathrm{O}_{5}$ & Rec. & (g) $\quad \mathrm{P}_{2} \mathrm{O}_{5}$ & Rec. \\
\hline Floats & 266.2 & 20.4 & 75.2 & 278.518 .578 .9 & 278.119 .9 & 78.3 & 236.220 .1 & 87.3 \\
\hline Tailings & 83.8 & 21.4 & 24.8 & $\begin{array}{lll}71.5 & 19.3 & 21.1\end{array}$ & $\begin{array}{ll}71.9 & 21.3\end{array}$ & 21.7 & $32.5 \quad 21.2$ & 12.7 \\
\hline Feed & 350.0 & 20.6 & 100 & 350.018 .6100 & 350.020 .2 & 100 & 350.015 .5 & 100 \\
\hline
\end{tabular}

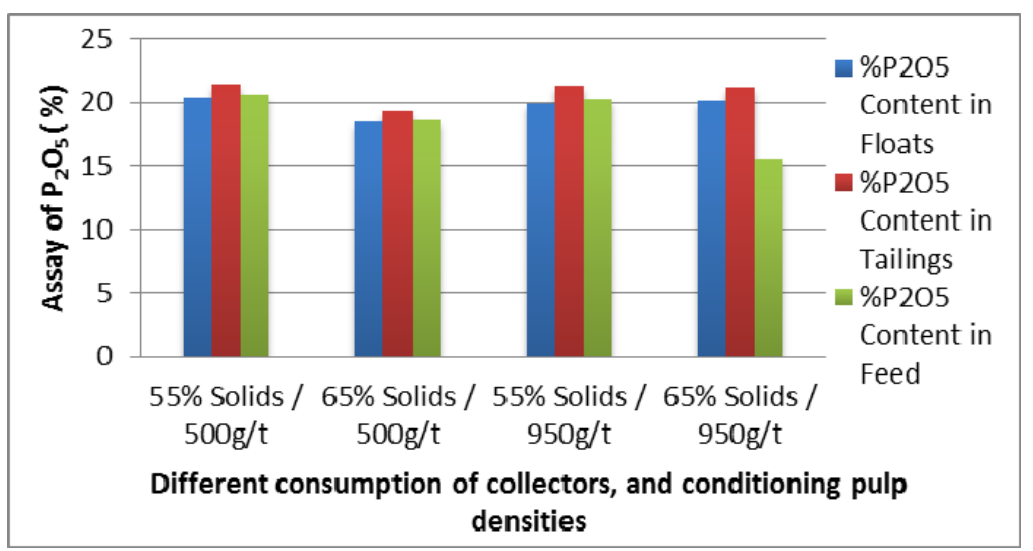

Fig. 7. \% Assay of $\mathrm{P}_{2} \mathrm{O}_{5}$ in the flotation samples of $-106+38 \mu \mathrm{m}$ at $\mathrm{pH} 10 / \mathrm{AERO} 04$ Promoter/MBIC(frother). 


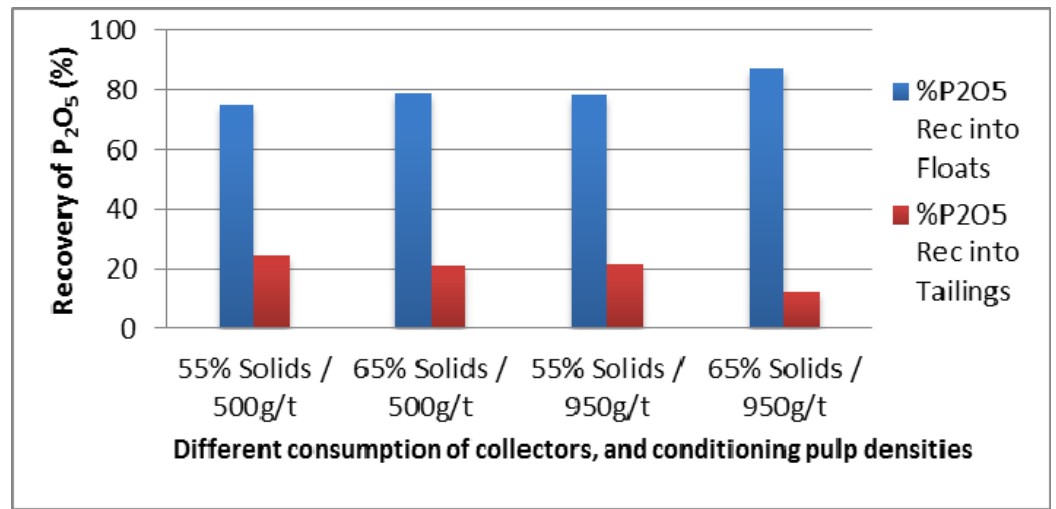

Fig. 8. \% Recoveries of $\mathrm{P}_{2} \mathrm{O}_{5}$ into floats produced during floatation test using $350 \mathrm{~g}$ of $106+38 \mu \mathrm{m}$ size fraction at 28.5\% solids with AERO704 Promoter (Distilled Tall-oil Fatty Acids) and Methyl isobutyl carbinol (MBIC) frother at pH10.

In comparison with the phosphate floated at $\mathrm{pH} 8$ using the same reagents, the average \% assay of $\mathrm{P}_{2} \mathrm{O}_{5}$ obtained is higher compared to those floated at a $\mathrm{pH} 10$, but with low $\%$ recoveries values. This phenomenon could be explained by the fact that Sokoto phosphate bearing minerals are sensitive to low basicity $\mathrm{pH}$ condition and higher above that, their qualities ( $\%$ assay) reduce while their recoveries increase.

\section{Conclusions}

The beneficiation parameters of Sokoto phosphate mineral ore have been determined for the beneficiation of the Sokoto phosphate mineral ore to a metallurgical grade for the production of fertilizer and phosphate related metallurgical products. The conclusions of the study were:

$>$ The separation of the chemical compound of the Sokoto phosphate mineral ore into float and tailings shows that the Sokoto phosphate ore could respond to froth flotation condition processes and hence could be beneficiated using froth flotation mineral processing technique.

The higher the $\%$ of solids floated the higher the tendency for more $\%$ of the phosphate bearing minerals to be collected in the float.

> Sokoto Phosphate ore is not amenable to beneficiation by flotation concentration arising from the poor separation of the phosphate bearing minerals from their associating gangue minerals due to poor liberation.

> AERO704 collector alone and without any depressant in floating Sokoto phosphate rock gave the best collector response than either Alkyl Hydroxamates or AERO704 combined with Diesel. 


\section{Reference}

[1] Food and Agriculture Organization. Use of Phosphate Rock for Sustainable Agriculture, Pp 54. 2002.

[2] Raw Materials and Development Council. Technical Brief on Mineral Raw Materials in Nigeria, Revised Edition, ISBN 978-8070-15-9. 2009.

[3] Zhang P. An Investigation of Flotation Reagents, FIPR 97-02-125, www.fipr.state.fl.us/FIPRreport2003/recently-completed-contractsbeneficiation.htm(Accessed 6/28/2010)

[4] Weiss, N.L., Mineral Processing Handbook, American Institute of Mining Metallurgical and Petroleum Engineering Incorporated in the United States of America, Kings Port Press, Pp 5/72 - 5/79; 21/1 - 21/17. 1985.

[5] Carr D. D. Industrial Minerals and Rocks, Society of Mining, Metallurgy and Exploration Inc, Pp751 - 764. 1994.

[6] Encyclopedia Britanica . www.britanica.com/EBchecked/topic/457399/phosphatemineral, accessed 28/6/2010

[7] Fuerstenau C. M. and Han N. K. Principles of Mineral Processing, Society for Mining, Metallurgy, and Exploration, U. S. A., PP245 - 306. 2003.

[8] Gruber G., Pilot Plant Demonstration of Anionic Rougher - Cleaner Flotation on Florida Phosphate, Final Report 02-151-200, FIPR 01-02-151, www.fipr.state.fl.us/FIPRreport2003/recently-completed-contracts-beneficiation. htm (Accessed 28/6/2010). 2003.

[9] GSD. Geological Survey Report on Sokoto Phosphate Deposit, Dange- Shuni LGA, unpublished. 1991.

[10] Gupta and Yan. Mineral Processing Design and Operations, PP555 - 621. 2006.

[11] Jones, M. P. Applied Mineralogy, A quantitative Approach, pp 13 - 69, 150 -176. 1987.

[12] Miller J. D. A Selective Collector for Phosphate Flotation, Final Report 02-142187, FIPR 00-02-142, 2003. www.fipr.state.fl.us/FIPRreport2003/recentlycompleted-contracts-beneficiation.htm , Accessed - 28/6/2010

[13] Mular, L., \& Bhappu, R. B., SME Mineral Processing Plant Design, $2^{\text {nd }}$ Edition, Pp113 - 306, $447-465.1980$.

[14] Nigerian Mining Corporation. Feasibility Study Report on Sokoto Phosphate Deposit, Dange-Shuni LGA, unpublished. 1991.

[15] Thomas, D.G., and Adewuyi, E.A. Effects of Local Frothers on the Flotation of Toto MuroIron Ore By. Proceedings of the $35^{\text {th }}$ Confer of the Nigerian Society of Chemical Engineers, Pp116-120. 2005.

[16] Thompson P. The Selection of Flotation Reagents via Batch Flotation Test. In: SME Mineral Processing Plant Design, Practice, and Control: Proceedings, Vols. 1, Pp137 - 144. 2002.

[17] Umar, A.H, Characterization and design process flowsheet for the Beneficiation of Sokoto phosphate, Ph.D Thesis, A.B.U., Zaria. 2014.

[18] Wills, B. A. and Napier - Munn, T. J. Mineral Processing Technology, $7^{\text {th }}$ edition Elsevier Science \& Technology Books, PP108-117; 267-352; 378-408) 2006.

[19] Yaro, S.A., Development of Process Route for the Beneficiation of MallamAyuba Manganese deposits to Ferromanganese feed grade, Ph.DThesis, A.B.U., Zaria. 1997. 